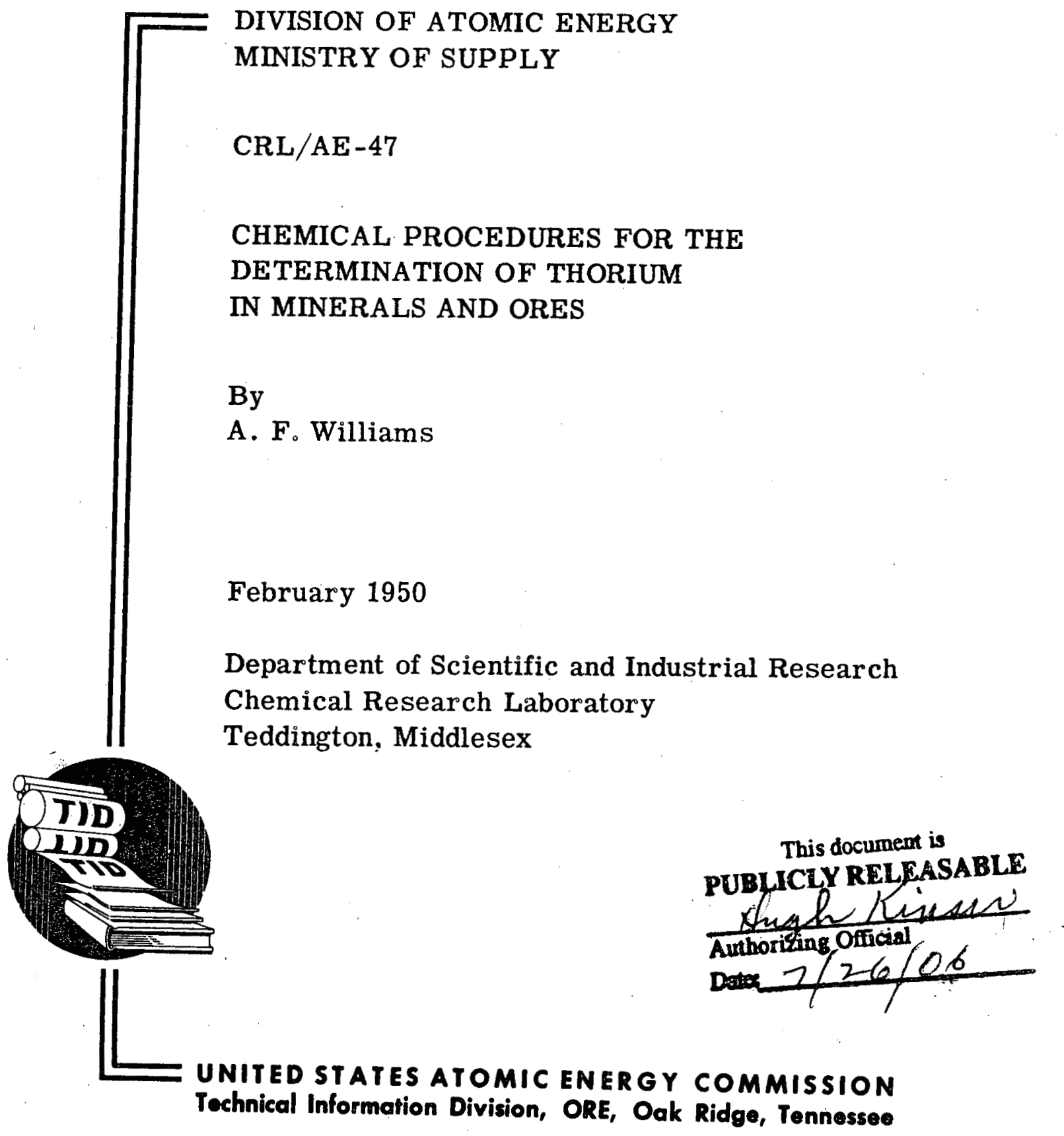

\title{
UNCI ASSIFIED
}

This report has been photostated to fill your request as our supply of copies was exhausted. If you should find that you do not need to retain this copy permanenty in your files, we would greatly appreciate your returning it to IIS so that it may be used to fill future requests from other AEC installations. 


\section{DISCLAIMER}

This report was prepared as an account of work sponsored by an agency of the United States Government. Neither the United States Government nor any agency Thereof, nor any of their employees, makes any warranty, express or implied, or assumes any legal liability or responsibility for the accuracy, completeness, or usefulness of any information, apparatus, product, or process disclosed, or represents that its use would not infringe privately owned rights. Reference herein to any specific commercial product, process, or service by trade name, trademark, manufacturer, or otherwise does not necessarily constitute or imply its endorsement, recommendation, or favoring by the United States Government or any agency thereof. The views and opinions of authors expressed herein do not necessarily state or reflect those of the United States Government or any agency thereof. 


\section{DISCLAIMER}

Portions of this document may be illegible in electronic image products. Images are produced from the best available original document. 
Styled, retyped, and reproduced from copy as submitted to this office.

$+$ 
CHEMICAL PROCEDURES FOR THE DETERMINATION OF THORIUM

IN MTNERAIS AND ORES

By A。F。Williams

\section{INTRODUCTION}

This report desoribes the principal chemical methods which are in use at the Chemical Research Laboratory for the determination of thorium in a wide variety of minerals and ores. This report represents a revision of some of the procedures recorded in an earlier report* in the light of experience gained during the past four years.

The method for decompostion of the ore has been standarized for most ores, including very refractory types. A procedure based on the use of $m-$ nitroberzoic acid is included for the precipitation and separation of thorium. This procedure has been extersirely used and, under tine conditions described, gives accurate results.

The methode are sitiable for the determination of thorium from a concentration of about 0.1 per cent $\mathrm{ThO}_{2}$ in the original ore up to practically pure thorium oxide (thorianite).

SCHEME OF ANALYSTS

Fuse ore with $\mathrm{KOH}$ and leach melt with $\mathrm{HCI}$

$$
\bigcup_{\text {See Procedures, Sec. } 1}
$$

Double oxalate precipitation (if pure monazite, do only one precipitation)

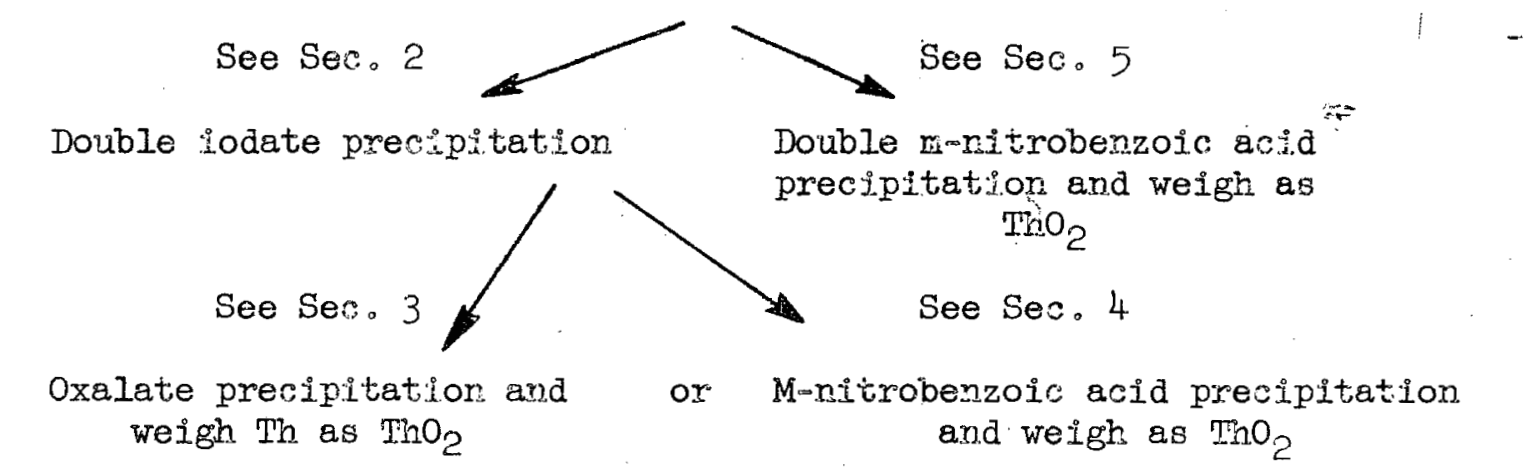

$\rightarrow$

*F. H。Brrstall and W。Ryan, CRL/AE-2, Chemical Methods for the Estimation of Thorium in Mineral Products.

$$
\mathrm{CRL} / \mathrm{AE}-47
$$


INTRODUCTORY NOTES ON ANALYTTCAL PROCEDURES

Decomposition of Ore

The method given under Procedurea ita a standard proeedure universally applicable to the decomposition of ores corfaining thorium and Is based on decomposition of the ore by fuston with at excess of potassium hydroxide. Details are given in Procedures, Sec。 $1_{3}$ steps 1 and 2 . Steps 3 and 4 deal with the extrastion of the cold potassiun kydroxide melt by hydrockloric and solution. The addition of a few drops of dilute isdrofluoric acid solution* exerts a catalytis effect in promoting solution of the fusion produst in the acid. This technique has been found particularly valuable for ores which contain zirconium. Eren so, a dear asid solution is not always obtained since silica, tin, and titaniun, for example, sometime separate as insoluble oxides due to hydrolysis. Experience has showa that any pretipitate obtained must not be filtered off at tiris stage.

Precipitation of Thorium and Rare-earth Oxalates

The acid solution of the potassium kydroxide melt is treated with oxalic acid in order to precipitate thorium and rare earthe as alates. It has been found that duririg this procedure much of the hydrolysis precipitate, which sonetime separates at step 4, dissolves in excess oxalic acid This solubility is a reason for not removing the insoluble naterial before oxalir acid treatment because auch material may contaix appreciable amounts of adsorbed thorium. Treatment of the oxalates and filter paper witin fuming or concentrated nitric acid is employed to destroy oxalic acid and convert thorium and rare earthe to soluble ritrates. By evaporating the solution just to the point where solids begin to separate, most of the eilica carred down with the precipitated oxalates is rendered insoluble on dilution with water (see Sec。 1 , step 10).

The eecond oxalic as:a presipitation described in step it is a further stage in the purifications of the thorium and rare earths and is only necessary. when the original ore contains gross amounts of silica, tin, titanium, ete. In the case of a pure monazite, it is possible to proseed direatly to the iodate separation (Sec.2) or moritrobenzoic acid separation (Sec.5). Whe a potassium hydroxide fusion is employed for decomposition of the ore, a preliminary oxalate or hydroxide separation is made in order to remove the bulk of the potassium salts derived from the fusion.

Precipitation of Thorium Iodate

The precipitations with potassiun iodate separate thorium from the rare earths. Only minor modifications have been introduced to the procedure as described in CRL/AE-2. The thorium is precipitated finally as oxalate (see Sec.3) or as meta-nitrobenzoate (see Sec.4).

*R. A。 WeIIs, unpublished work. 
Procedure Employing m-Nitrobenzoic Acid for Separation of Thorium from Rare Earths

A useful method for separation of thorium from rare earths involves precipitation with m-njtrobernzoice acid.* Under the conditions given in Secs. 4 and 5, thorium forms an insoluble m-xitrobenzoate, but those of the rare earths are soluble. The procedure is employed directly after the oxalate precipitations. If the amount of rare earths present are appreciable, a doidble precipitation is used. The method is considerably quicker than the ioclate procedure and possesses the advaritage that the precipitate filters raiplaly and is ignited directly to $\mathrm{ThO}_{2}$. Control of $\mathrm{pH}$ of the solution before addition of m-nitrobenzolo acid lo important, and the technique employed by Nelsh, namely, adjustment to methyl orange indicator, is not well suited to routine work. The use of acetic acid (see Sec. 4 and 5) for adjustment of the $\mathrm{pH}$ of the alkaline solution containing thorium and rare earthe allows considerable latitude, and the modifled procedure has been shown to give reliable results. The m-nitrobenzoic acid method can be used in the presence of ceric salts; whereas if the lodate separation is employed, the cerium must be in the reduced form. Sulfates must not be present in solution wien thorium is to be precipitated by m-nitrobenzoic acid since such material inhibits precipitation of thorium.

\section{PROCEDURES}

Sec. 1. Decomposition of Ore and Separation of Thorium and Rare Eartho

1. Heat 8 to $10 \mathrm{~g}$ of $\mathrm{KOH}$ (use aralar $\mathrm{KOH}$ pellets) to red heat in a nickel crucible ( 5 in. diameter and $4 \frac{1}{2}$ in. deep), maintain at this temperature for about $5 \mathrm{~min}$ (in order to remove water), and then allow to cool.

2. Welgh accurately about $1 \mathrm{~g}$ of sample and gently transfer to the surface of the cold $\mathrm{KOH}$ melt. Replace the crucible lid, slowly raise the temperature of the crucible, and maintain at red heat for about $45 \mathrm{~min}$ (A pure monazite may be decomposed in a shorter.period of time. The amount of sample taken should be adjusted to give not more than about $0.25 \mathrm{~g}$ of $\mathrm{ThO}_{2} \mathrm{l}$.

3. Place $100 \mathrm{ml}$ of water and $50 \mathrm{ml}$ of $\mathrm{BCl}$ (conc.) in a 600-ml beaker. Quickly leach the cold $\mathrm{Ni}$ crucible and lid and remove them with the aid of a pair of tongs, washing well with distilled water.

4. Bring the contents of the beaker to boiling point and addrone or two drops of dilute HF solution ( 1 volume of $\mathrm{HF}(40 \% \mathrm{w} / \mathrm{F})$ and 20 volumes of water), continue boiling for about $15 \mathrm{~min}$ and allow to cool (See section on decomposition of ore under Introductory Notes).

5. Add ammonia solution ( $\mathrm{sp}$ gr 0.880 ) to the beaker with stirring and then make just acid by addition of $\mathrm{HCl}$ (conc.) and adjust the volume to $400 \mathrm{ml}$.

6. Bring the solution again to boiling point, add slowly a hot solution of $12 \mathrm{~g}$ of oxalic acid in 10 to $20 \mathrm{ml}$ of water, and stir well. Continue boiling while adding 10 to $12 \mathrm{ml}$ of $\mathrm{ECl}$ (cone.) and then set the beaker on one side for about $6 \mathrm{hr}$ or allow to stand overnight.

*First described by Neish, J。Am。Chem。Soco, 26: 780 (1904)。 
T. Filter the oxalate preosptate using a No. 42 Whatmen paper and wash the oxalates with cold oxalie acid solution (Dissolge $2 \mathrm{~g}$ of oxalic acid $1 \mathrm{n} 100 \mathrm{ml}$ of water acidified with a few drops of corc。 ECl).

8. Place the filter paper and oxalate precipitate in the original beaker, add 20 to $30 \mathrm{ml}$ of $\mathrm{HNO}_{3}$ (cone) axd 5 to $10 \mathrm{ml}$ of perchloric acid $(60 \% \mathrm{w} / \mathrm{v})$, and cover with a clock glass.

9. With the beaker covered, evaporate the solution on a hot plate in a fune cupboard to about $3 \mathrm{ml}$, add $20 \mathrm{ml}$ of $\mathrm{HNO}_{3}$ (cons.), and re-evaporate almost to dryness so that the residue has the appearance of being just. molst.

10. Add $1 \mathrm{ml}$ of $\mathrm{HNO}_{3}$ (conco) axd $25 \mathrm{ml}$ of water. Boil the solution and fulter through a No. 541 paper containing a little paper pulp. (Susperd a few grams of Whatman paper clippings (No.42) in water in a stoppered conical flask and shake vigorously。) Wash with hot water. (Avidify with a few drops of $\mathrm{HCI}$ (conc.).

11. Dilute the filtrate to a volume of $250 \mathrm{ml}$, make just alkaline with ammonia (litmus) (sp gr 0.880), and ther make just asid with HCl.

12. Repeat step 6; but since the volume of solution is now only $250 \mathrm{ml}$, use 8 to $10 \mathrm{~g}$ of oxalic acsd and 8 to $10 \mathrm{ml}$ of cons. HCl. Repeat steps 7 , 8 , 9 , and 10 .

13. To the solution, the volume of which should be $100 \mathrm{ml}$, add $50 \mathrm{ml}$ of $\mathrm{HNO}_{3}$ (conc.). Add a few drops of $\mathrm{H}_{2} \mathrm{O}_{2}$ (20 vol) with stirring and heat to reduce ceric ions to cerous. Do not add more than 1 drop excess of $\mathrm{H}_{2} \mathrm{O}_{2}$, or iodine will be liberated at step 7 , Sec. 2 .

Sec.2。 Iodate Separation of Thorium and Rare Earths

1. Slowly add $16 \mathrm{~g}$ of $\mathrm{KIO}_{3}$ dissolved in a mixture of $50 \mathrm{ml}$ of $\mathrm{HNO}_{3}$ (conco) and $30 \mathrm{ml}$ of water. Stir continuously. Cool to room temperature, on iee if necessary.

2. Filter through a No. 541 filter paper ard wash the iodate as completely as possible on to the paper wath iodate wash solution $\left(8 \mathrm{~g}\right.$ of $\mathrm{KIO}_{3}$ and $50 \mathrm{mI}$ of $\mathrm{HNO}_{3}$ (conc。) diluted to 1 liter, with distilled water), as as about $100 \mathrm{ml}$ of wash liquor. Small volumes of wasts liquor with frequent drainisgs should be employed.

3. Remove the filter furnel and carefully wash out the preciplate with distilled water (50 to $100 \mathrm{ml}$ ) into a 400-ml beaker. Raise the suspension nearly to the boiling point and add $30 \mathrm{ml}$ of aitric acid (conc.) in small amounts. Complete solution should be obtained. Reserve the filter paper and use again in step 5. Stand the furinel over a beaker.

4. Dissolve $4 \mathrm{~g}$ of $\mathrm{KIO}_{3}$ (sufficient to precipitate $0.25 \mathrm{~g}$ of $\mathrm{TnO}_{2}$ ) in $15 \mathrm{ml}$ of boiling water and add this to the hot thorium solution from step 3. Stir well and tien cool to room temperature, or ite if necessary.

5. Filter the thorium jodate suspension using the original filter paper reserved from step 3. Wash the precipitate with about $100 \mathrm{ml}$ of lodate wash solution (see step 2).

6. Wash off the precipitate (as described in step 3) into the original beaker, using 50 to $100 \mathrm{ml}$ of distflled water. Stand the funnel over a beaker. 
7. Add $20 \mathrm{ml}$ of Fil (mone) to the thoriun iodate suspersion, wam and pass $\mathrm{SO}_{2}$ gas until a elear solution $2 \mathrm{~s}$ obtained, and then pass sufficient $\mathrm{SO}_{2}$ gas to give a silgit exiess.

8. Filter the soluson through the original paper (see step 6) ard pour the filtrate agaln througt the paper If iodine is liberated ix the colutior, irsufficient $\mathrm{SO}_{2}$ has been passed through the solutioz at step ?. Wash the paper thorongily with hot distilled wates.

9. Boil the filtrate to remove dissolved $\mathrm{SO}_{2}$ gas. Make the solution just amoniacal Fist armoria (sp gr 0.880). Filter the hydroxide prestpitate and wash with dilute ammoria solution (Add $5 \mathrm{~g}$ of $\mathrm{NH}_{4} \mathrm{Cl}$ and a few drops of $\mathrm{NH}_{4} \mathrm{CH}(\mathrm{O} .880)$ to $500 \mathrm{ml}$ of distilled water).

Sec. 3. Oxalate Procedure for Final Determination of Thorium

1. Mix $10 \mathrm{ml}$ of $\mathrm{HCl}$ (conc.) and 40 to $50 \mathrm{ml}$ of water, heat to the boiling point, and then pour through the filter paper to dissolve the precipitated hydroxides from Ses. 2, step 9. Heat tise filtrate and pour this through the same paper. Thoroughly wash the paper with hot distilled water. The filtrate and washings must have a final volume of about $250 \mathrm{ml}$. Make the solution just alkaline with amonia and then just acid with HCI.

2. Heat the solution to the bolling point, add a hot solution of $10 \mathrm{~g}$ of oxalj.c acid in $20 \mathrm{ml}$ of water, ard stir vigorous $1 \mathrm{y}$. Add 8 to $10 \mathrm{ml}$ of HCl (conc.) while the solution 18 still boiling and set, aside to rool and stand, preferably overnight.

3. Filter the oxalate precipitate on a No. 42 Wratinan filter paper, wash with oxalio acta wash solution (see Sec, 1, step 7), and then ignite the paper ard precipitate in a tared platirux cricible. (Firally, jenite strongly at about, $850^{\circ} \mathrm{c}$ )

4. Weigh the $\mathrm{ThO}_{2}$ ard express the result as $\% \mathrm{TrO}_{2}$ in the original ore.

See. 4. Mete-nitrobenzoir. Aeid Procedure for Final Detemination of Thorium

1. Dissolve tre hydroxide precipitate from sec.2, step 9, in hydrochloric acid by powing hot dilute Hol solution through the paper containing the hydroxides of thorivin and rare earths; collect in a 400-mi beaker.

2. Evaporate the HCl solution to a rolume of about $2 \mathrm{mil}$. Dilute to 20 to $25 \mathrm{ml}$ with water, add a few drops of brompherol blue indicator and strong ammonia (sp gr 0.880) solution (contalned in a droppsing bottle) vatil the solution is just blue. (A permanent precipitate forms.)

3. Add glacial acetic acid from a droppirig bottle urtil the precipitate just dissolves and the blue color of the indicator turris greenish violet.

4. Add 15 to 20 drope excess of acetic acid and ther $250 \mathrm{ml}$ of a saturated solution of meta-mitroberizoic acid (Add $4 \mathrm{~g}$ of meta-nitrobenzoic acid to 1 liter of distilled water. Fieat to $80^{\circ} \mathrm{C}$ on the steam batis, cool, ard filter; $250 \mathrm{ml}$ is suffeies to prespitate about $0.15 \mathrm{~g}$ of $\mathrm{Tr}_{2} \mathrm{O}_{2}$ ). Stir well and ther heat to $80^{\circ} \mathrm{C}$ (approximately) for about $20 \mathrm{~min}$.

5. Filter the hot solution through a Whatman No. 541 filter paper (The precipitate is very asily fillered and washed) 
6. Wash the precipitate thoroughly with a cold wash solution of metanitrobenzoic acid ( $5 \mathrm{ml}$ of the saturated $\mathrm{m}$-nitrobenzoic acid solition added to $100 \mathrm{ml}$ of water). Ignite the precipitate and weigh as ThO 2 .

Sec. 5. M-nitrobenzoic Acid Separation of Thorium

1. After destmuction of the final oxalate precipitate (Sec. I) with $\mathrm{FNO}_{3}$, add I ml of $\mathrm{HNO}_{3}$ (cone.) to the moist residue and dilute the solution to 20 to $25 \mathrm{ml}$.

2. Add a few drops of bromphenol blue fndicator to the solution and then add ammonia ( $\mathrm{sp}$ gr 0.880) from a dropping bottle until the solution is just blue (with formation of a permanent precipitate). Add glacial acetic acid drop by drop until the solution becomes greenish violet and the precipitate just dissolves. Add 15 to 20 drops in excess and then $250 \mathrm{ml}$ of a saturated solution of m-nitrobenzoic (see Sec. 4, step 4) acid. Stir well and heat the solution to about $80^{\circ} \mathrm{C}$ for 20 min.

3. Filter the hot solution through a No. 54I Whatmar filter paper and wash with m-nitrobenzoic acid wash solution (See Sec. 4, step 6).

4. Dissolve the precipitate in dilute nitrice acid solution by pouring a hot solution of $6 \mathrm{ml}$ of $\mathrm{HNO}_{3}$ (conc.) and $14 \mathrm{ml}$ of water through the paper containing the precipitate. (Reheat the filtrate and again pour the hot solution through the No. 541 paper.) Wash the filter paper with hot water acidified with nitric acid.

5. Evaporate the solution to about $5 \mathrm{ml}$. Dilute the solution to 20 to $25 \mathrm{ml}$ with water, add a few drops of bromphenol blue indicator solution, and continue as described in steps 2 and 3 . Ignite the final precipitate of thorium-m-nitrobenzoate to $\mathrm{ThO}_{2}$ and weigh. 
C-ARalyrical Propedures

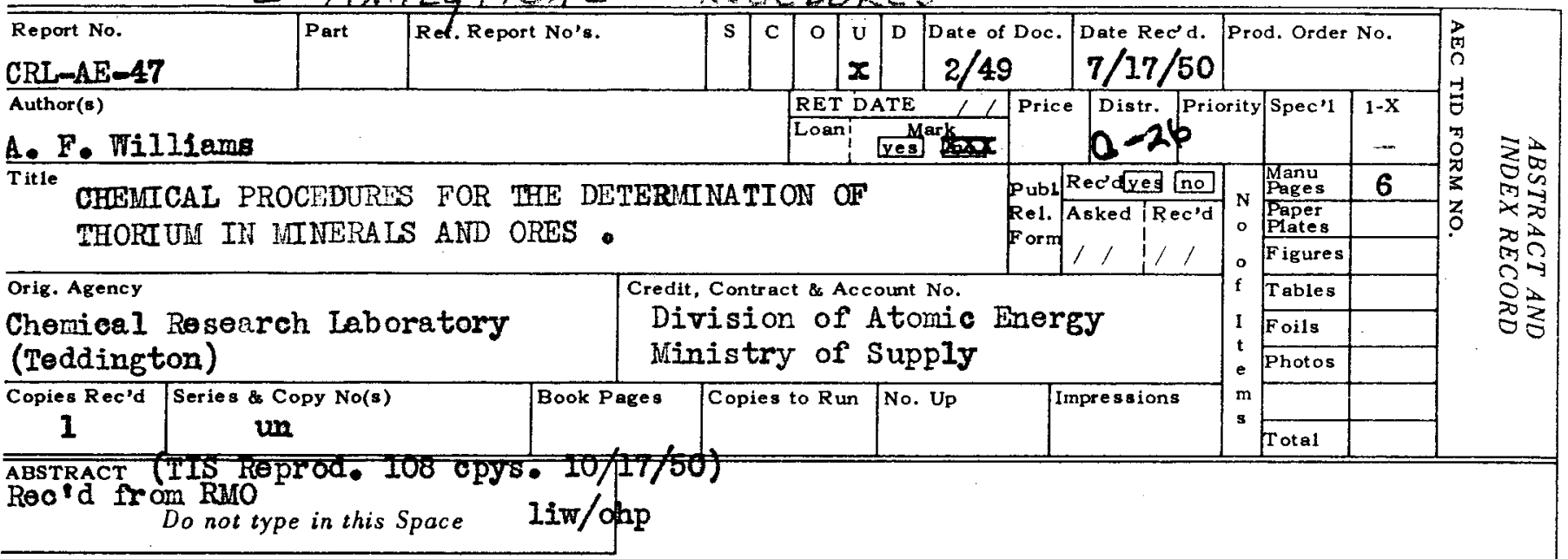

The principal chemical methods at present in use at the Chemical Research

Iaboratary, Teddington. England for the determination of thorium in a wide variety of minerals and ores are presented. The method for decomposition of the ore has been standarized for most ores, including very refractory types. A procedure based on the use of m-nitrobenzoic acid is included for the precipitation and separation of thorium. This procedure has been extensively used and, under the conditions described, gives accurate results. The methods are suitable for the deternination of thorium from a concentration of about $0.2 \%$ Thof in the original ore up to practically pure thorium oxide (thorianite).

$11-20-50$

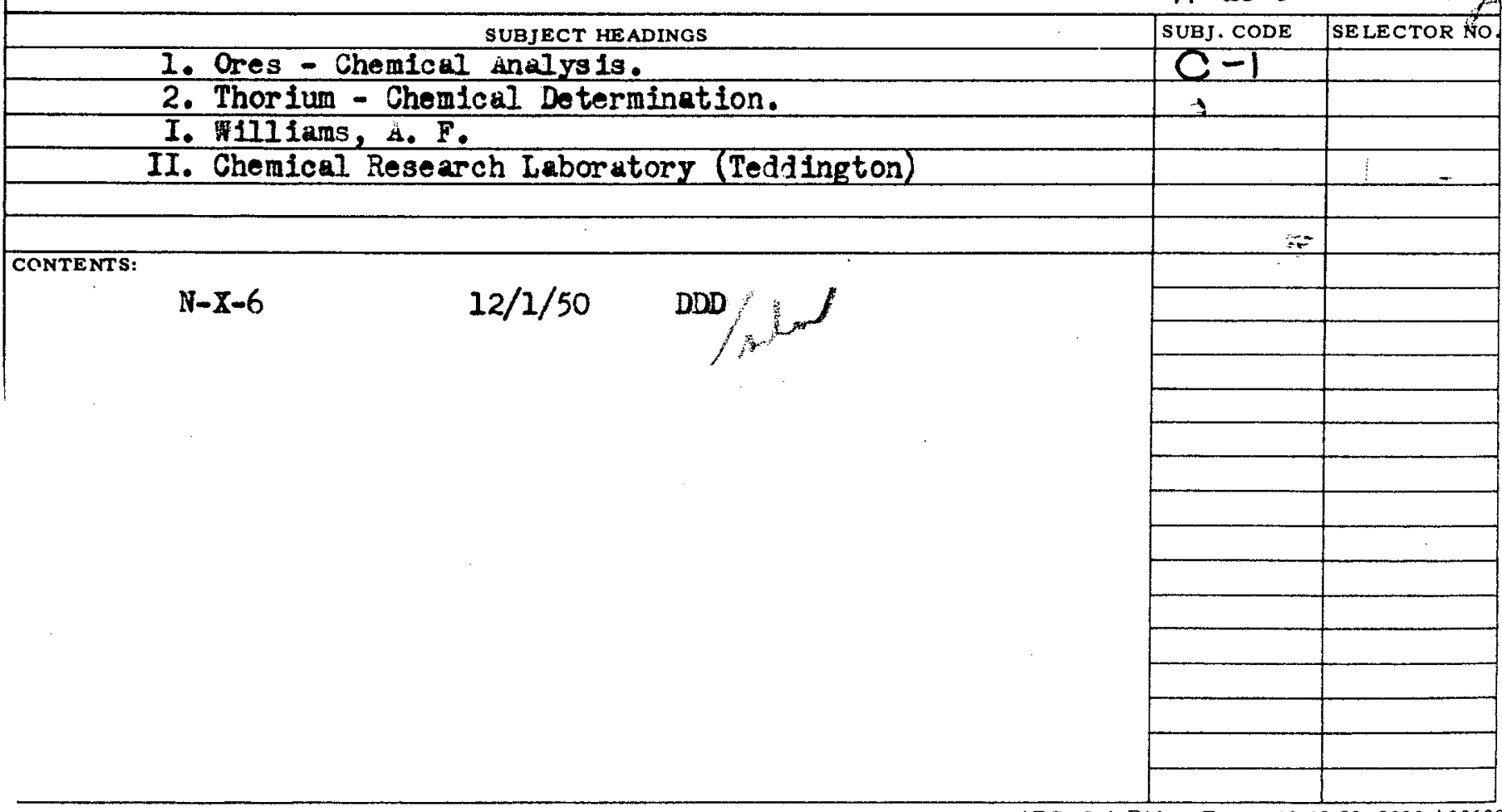

